Article

\title{
Microscopic Blue Sapphire in Nelsonite from the Western Adirondack Mountains of New York State, USA
}

\author{
Robert S. Darling ${ }^{1, *}$, Jessica L. Gordon ${ }^{2}$ and Ellis R. Loew ${ }^{3}$ \\ 1 Department of Geology, State University of New York, College at Cortland, Cortland, NY 13045, USA \\ 2 Hommocks Middle School, 130 Hommocks Road, Larchmont, NY 10538, USA; jgordon@mamkschools.org \\ 3 Department of Biomedical Sciences, T8-004 Veterinary Research Tower, Cornell University, Ithaca, \\ NY 14853-6401, USA; erl1@cornell.edu \\ * Correspondence: robert.darling@cortland.edu; Tel.: +1-607-753-2923
}

Received: 31 July 2019; Accepted: 8 October 2019; Published: 16 October 2019

\begin{abstract}
Microscopic, non-gem quality, grains of blue sapphire (corundum) have been identified in a small (1-2 cm wide), discontinuous, dike of nelsonite hosted by aluminous feldspathic gneiss. The gneiss was excavated during the construction of a hydroelectric plant on the Black River at Port Leyden, NY (western Adirondack Highlands). The sapphire location is $250 \mathrm{~m}$ NE of the Port Leyden nelsonite deposit. The small dike may represent a separate intrusion of nelsonite or one sheared from the main nelsonite orebody during Ottawan (circa $1050 \mathrm{Ma}$ ) deformation and metamorphism. The sapphires range in size from 0.1 to $2.0 \mathrm{~mm}$, and commonly show parting, pleochroism, and hexagonal oscillatory zoning (from deep blue to clear). Electron microprobe analysis shows comparable levels of Fe in both clear $(0.71-0.75 \mathrm{wt}$. \%) and blue (0.38-0.77 wt. \%) portions of grains, but clear sections have significantly lower $\mathrm{TiO}_{2}$ levels (0.002-0.011 wt.\%) compared to blue sections (0.219-0.470 wt. \%). $\mathrm{Cr}_{2} \mathrm{O}_{3}$ abundances range from 0.006 to 0.079 wt. \% whereas $\mathrm{V}_{2} \mathrm{O}_{3}$ abundances range from 0.010 to $0.077 \mathrm{wt}$. \% in blue sapphires. Small amounts of $\mathrm{MgO}$ were detected in one of the clear corundum grains $(0.013 \mathrm{wt}$. \%) and two of the six blue grains $(0.001-0.015 \mathrm{wt}$. \%), but the remaining five grains were below the limit of detection. $\mathrm{Ga}_{2} \mathrm{O}_{3}$, however, was detected in five out of six blue-colored grains $(0.026-0.097 \mathrm{wt}$. \%) but was below the limits of detection for clear grains. Optical spectroscopic data collected on the blue sapphire grains show broad absorbance in the yellow, orange, and red part of the spectrum ( $565-740 \mathrm{~nm})$ consistent with intervalence charge transfer between the next nearest neighbor $\mathrm{Fe}^{2+}$ and $\mathrm{Ti}^{4+}$. A magmatic origin of the sapphire grains is supported by petrologic and trace element data from the blue sapphires, but $\mathrm{Cr}$ abundances are inconsistent with this interpretation. Sapphire in a nelsonite host rock represents a new type of occurrence.
\end{abstract}

Keywords: blue sapphire; corundum; nelsonite; Adirondacks

\section{Introduction}

Gem corundum deposits worldwide are generally associated with quartz-free rocks of both igneous and metamorphic origin. Corundum in syenites and monzonites is thought to be of primary origin, whereas corundum in alkaline basalts, lamprophyres, and andesites is thought to originate as xenocrysts [1-3]. Metamorphic and metasomatic corundum has been described in meta-limestone, mafic granulites, aluminous gneisses and granulites, skarns, and desilicated pegmatites, plumasites, and gneisses [1,2]. Here, we report a new type of occurrence of strongly blue-colored, microscopic, corundum (blue sapphire) from a small nelsonite dike hosted by aluminous gneiss in the western Adirondack Highlands of New York State. Nelsonites are unusual Fe-Ti-P rich igneous rocks noted for their high concentration of Ti and may be economically important [4-7]. Nelsonites are silica-poor 
but are normally not considered a potential source of sapphire. To our knowledge, this is the first description of sapphire from a nelsonite. In this report, we discuss the petrography, mineral chemistry, optical spectroscopy, and inferred origin of this sapphire occurrence.

\section{Study Area}

The microscopic grains of blue sapphire occur in a small, discontinuous dike (1-2 cm wide) of nelsonite hosted by Middle Proterozoic aluminous gneiss. Samples of the aluminous gneiss were excavated during construction of a hydroelectric plant on the Black River at Port Leyden, NY (western Adirondack Highlands) located at $43.58654^{\circ} \mathrm{N}$ and $75.33874^{\circ} \mathrm{W}$ (Figure 1a). The sapphire location is 250 m northeast of the Port Leyden nelsonite (Figure 1b; [8]). It is unclear how the small, sapphire-bearing, nelsonite dike is related to the larger, nelsonite orebody. The sapphire-bearing nelsonite may represent an entirely separate intrusion, or it may represent a small lens sheared from the Port Leyden nelsonite during deformation associated with the Ottawan phase of the Grenville Orogeny [9,10]. The latter interpretation is consistent with the northeast strike of the regional foliation (Figure 1b).

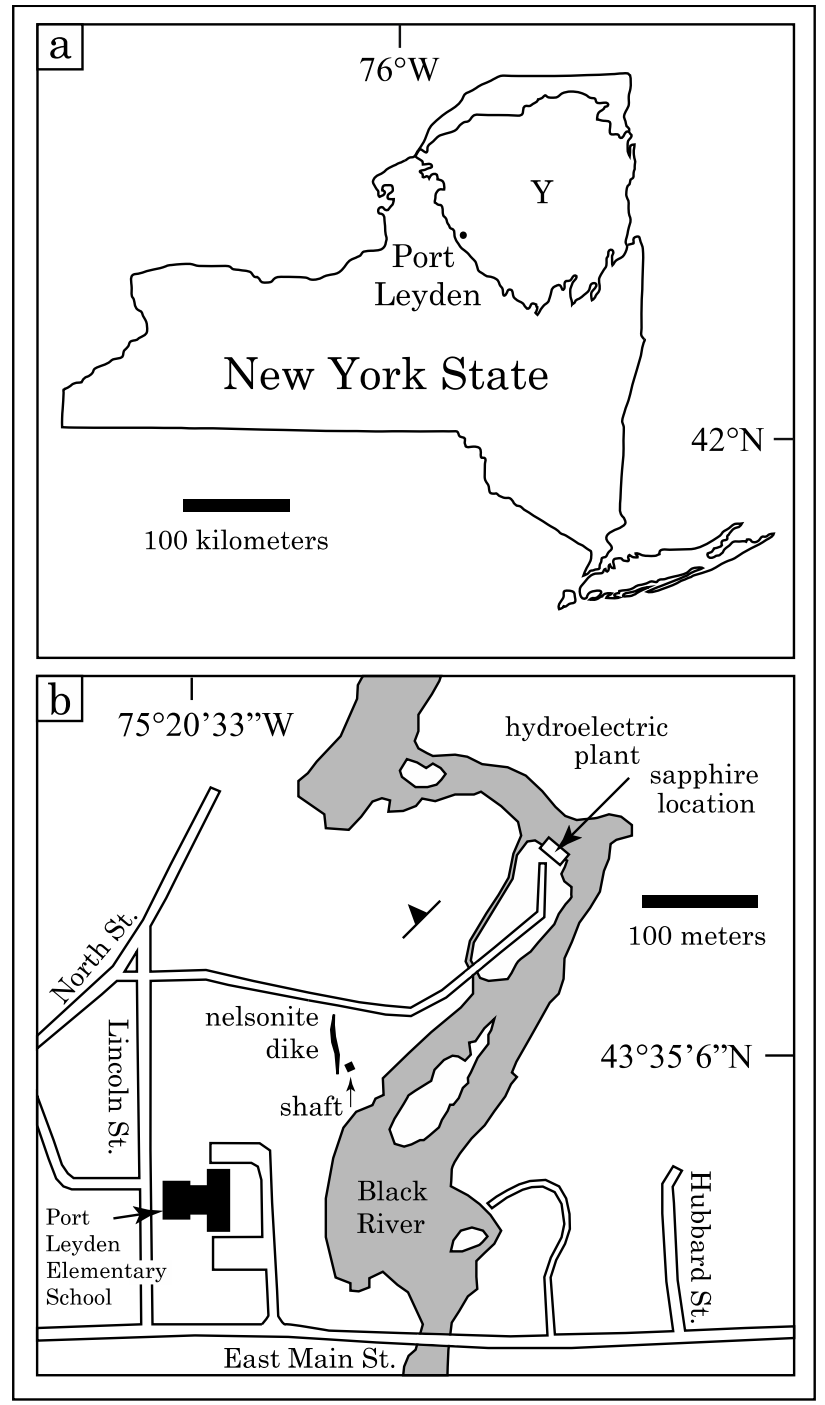

Figure 1. (a) Location map showing Middle Proterozoic (Y) rocks of the Adirondack Mountains in upstate New York and the village of Port Leyden. (b) Map of the eastern part of the village of Port Leyden showing location of the Port Leyden nelsonite dike, the hydroelectric plant on the Black River where the sapphire-bearing nelsonite dike was extracted, and strike and dip direction of foliation in the surrounding metapelite gneiss. 


\section{Geologic Setting}

The aluminous gneisses in the study area were formed during the Ottawan phase of the Grenville orogenic cycle, which lasted from about 1090 to 1020 Ma [9,10]. In the western Adirondack Highlands, this event was characterized by deep burial, granulite-facies metamorphism, intense shearing, and local intrusion of granitic igneous rocks [10]. In the immediate study area, estimates of metamorphic temperature and pressure were provided by [11] and revised slightly by [12], who determined conditions of at least $780{ }^{\circ} \mathrm{C}$ and $6.0 \pm 0.5$ kilobars. These estimates are based on hercynite-silicate equilibria and biotite melting reactions. About $14 \mathrm{~km}$ to the east of the study area, [13] determined metamorphic pressure-temperature conditions of $6.6 \pm 0.6 \mathrm{~kb}$ and $850 \pm 20^{\circ} \mathrm{C}$ for orthopyroxene + garnet assemblages in metapelites. The $\sim 850{ }^{\circ} \mathrm{C}$ temperatures were later verified by Ti-in-quartz geothermometry on the same rocks [14]. All thermobarometric studies in the area demonstrate granulite-facies conditions during the Ottawan metamorphism, conditions consistent with some sapphire-forming environments in other regions of the world [1,2].

Although the sapphire-bearing sample was not collected from the Port Leyden nelsonite, $250 \mathrm{~m}$ to the southwest, a description of this rock is necessary as the sapphire-bearing sample could have been sheared from this orebody or intruded along with it. The Port Leyden nelsonite is a fine-grained, phaneritic, magnetite + apatite + ilmenite + pyrite + monazite + zircon igneous rock with lesser quantities of garnet \pm secondary chlorite [8]. It has a weak, pyrite-defined foliation [15]. The orebody is oriented roughly north-south, is about 3 to $4 \mathrm{~m}$ wide, and is exposed at the surface for about $30 \mathrm{~m}$.

\section{Petrography}

The sapphire-bearing sample (93-BD-35) is a medium-grained, plagioclase + biotite + microperthite + garnet + quartz + sillimanite \pm hercynite gneiss that hosts a 2 -cm wide dike of sapphire-bearing nelsonite (Figure 2). The quartz \pm hercynite assemblage of the country rock is not in textural equilibrium with sapphire-bearing nelsonite. The small nelsonite dike comprises fine-grained, phaneritic, magnetite, apatite, ilmenite, corundum (sapphire), hercynite, monazite, zircon and pyrite. Contacts with the country rock are sharp. The aluminous gneiss at the contact with the sapphire-bearing nelsonite is characterized by plagioclase, biotite and new growth of garnet. Quartz, although present throughout the aluminous gneiss, is absent within $1 \mathrm{~cm}$ of the dike. The sapphire-bearing nelsonite dike is identical to the Port Leyden nelsonite, except that the ilmenite is largely replaced by post-metamorphic rutile and calcite and by the presence of corundum and hercynite. The proximity of the two nelsonite dikes and the overall similar mineralogy suggests both have a common origin. Both nelsonite dikes are inferred to predate deformation and metamorphism associated with the Ottawan phase of the Grenville Orogenic cycle. The sapphire-bearing sample (93-BD-35) and thin sections of it are now part of the permanent collection of the New York State Museum, in Albany NY, USA.

The sapphire grains range in size from 0.1 to $2.0 \mathrm{~mm}$, and tend to fill voids between earlier formed apatite, magnetite, ilmenite, and zircon grains (Figure 3). The sapphires show both clear and homogeneously blue-colored areas (Figures 3 and 4 ) and show typical corundum parting along $\{10 \overline{1} 1\}$ [16]; Figure 4b). The sapphires also show fine, hexagonal oscillatory zoning (Figure $4 b-d$ ) and are pleochroic (Figure 5a,b). Remarkably, the blue color of the sapphires is very deep, despite a thin section thickness of only $30 \mu \mathrm{m}$. Whereas corundum grains are commonly a little thicker in a standard thin section because of their high hardness, the grain shown in Figure 4a was measured at $35 \mu \mathrm{m}$ thick.

Note in Figure 4d, the jagged growth sector boundary between the upper and lower zoned halves. This is inferred to be the result of fluctuations in the relative growth velocity [17] between the hexagonal prism faces $\{11 \overline{2} 0\}$. Also, note stronger colors of blue are generally associated with an angle of less than $120^{\circ}$ between the growth sector boundary and the growth zone, and, clearer areas are associated with an angle of more than $120^{\circ}$ between the growth sector boundary and the growth zone. This suggests that slower crystal growth $\left(<120^{\circ}\right.$ angles) may have resulted in greater incorporation of $\mathrm{Fe}^{2+}$ and $\mathrm{Ti}^{4+}$ into the corundum structure rendering them bluer in color (see following section). 


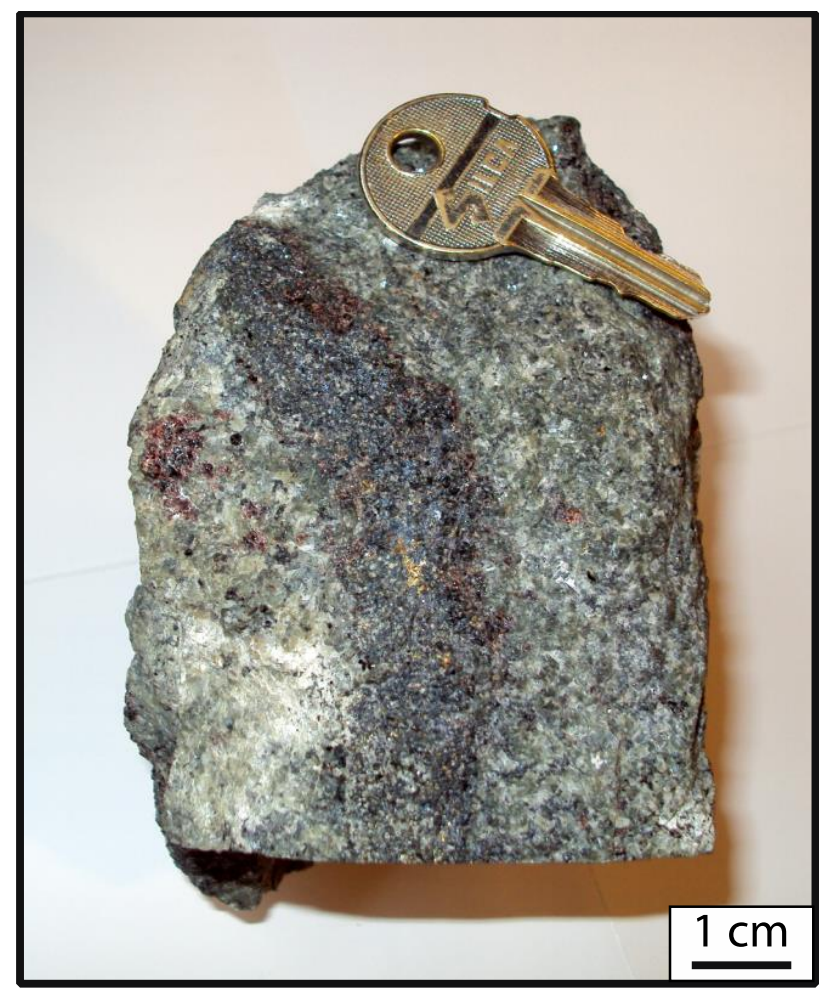

Figure 2. Photograph of rock sample 93-BD-35 containing the 2-cm wide nelsonite dike (dark, in center) cutting feldspar + garnet + biotite + quartz + sillimanite \pm hercynite gneiss (greenish-gray). The small nelsonite dike contains microscopic sapphires. The dike may have experienced shearing during the Ottawan phase of the Grenville Orogeny.
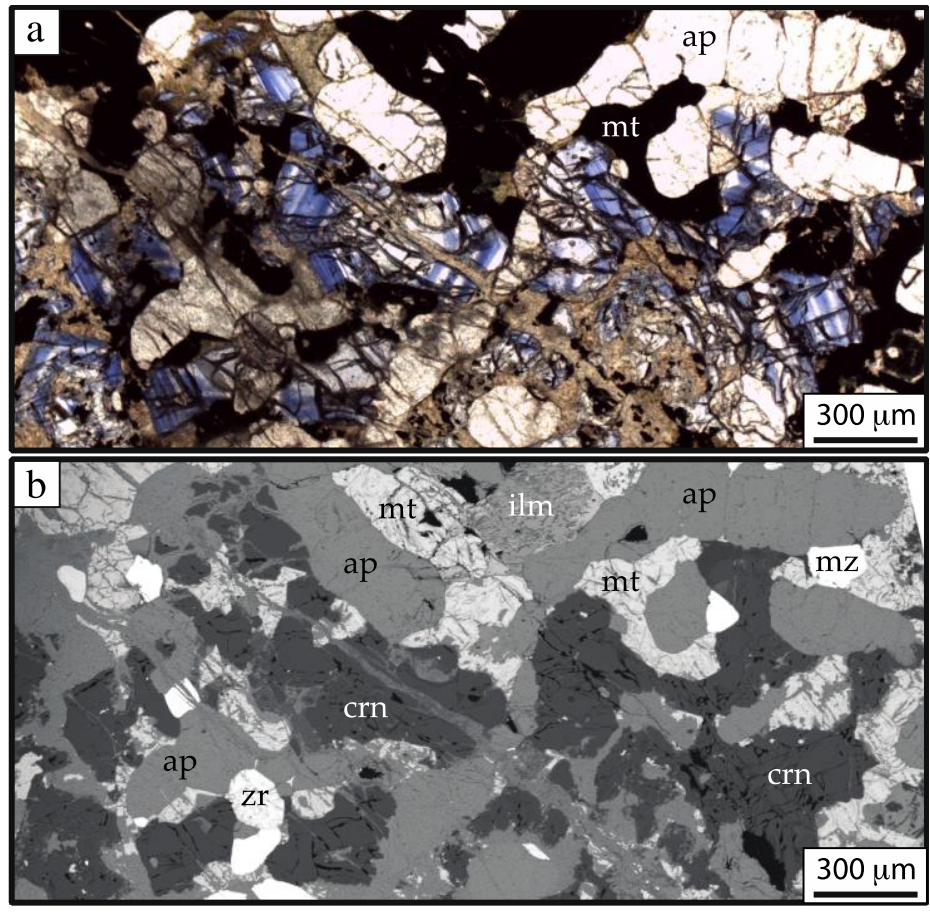

Figure 3. Low magnification images of sapphire-bearing nelsonite. (a) Photomicrograph of blue sapphire in plane-polarized light. (b) backscattered electron image of same area. Corundum (crn) is surrounding by grains of apatite (ap), magnetite ( $\mathrm{mt}$ ), ilmenite (ilm) being replaced by rutile and calcite, zircon (zr), and monazite (mz), and patches and fracture fillings of retrograde mixture of chlorite and biotite (brown in optical image). Note, hexagonal zoning in and void-filling texture of sapphire. 


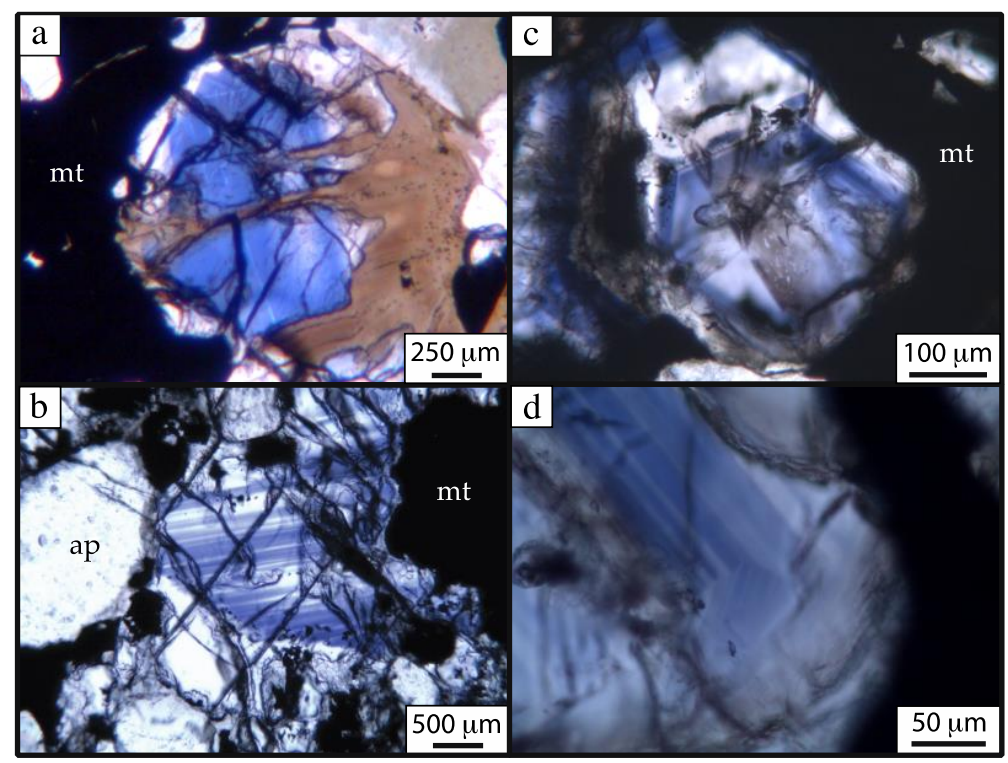

Figure 4. Photomicrographs of blue sapphire in plane-polarized light surrounded by magnetite (mt) and apatite (ap). (a) Fractured grain with deep-blue color, replaced by a fine-grained mixture of retrograde chlorite and biotite (brown), (b) sapphire showing typical rhombohedral parting and oscillatory zoning between blue and clear sections, (c) sapphire viewed perpendicular to (0001), showing typical clear and strongly blue colored hexagonal zoning, (d) sapphire showing fine oscillatory zoning. Note, jagged growth sector boundary between the upper and lower zoned halves (see text for discussion).

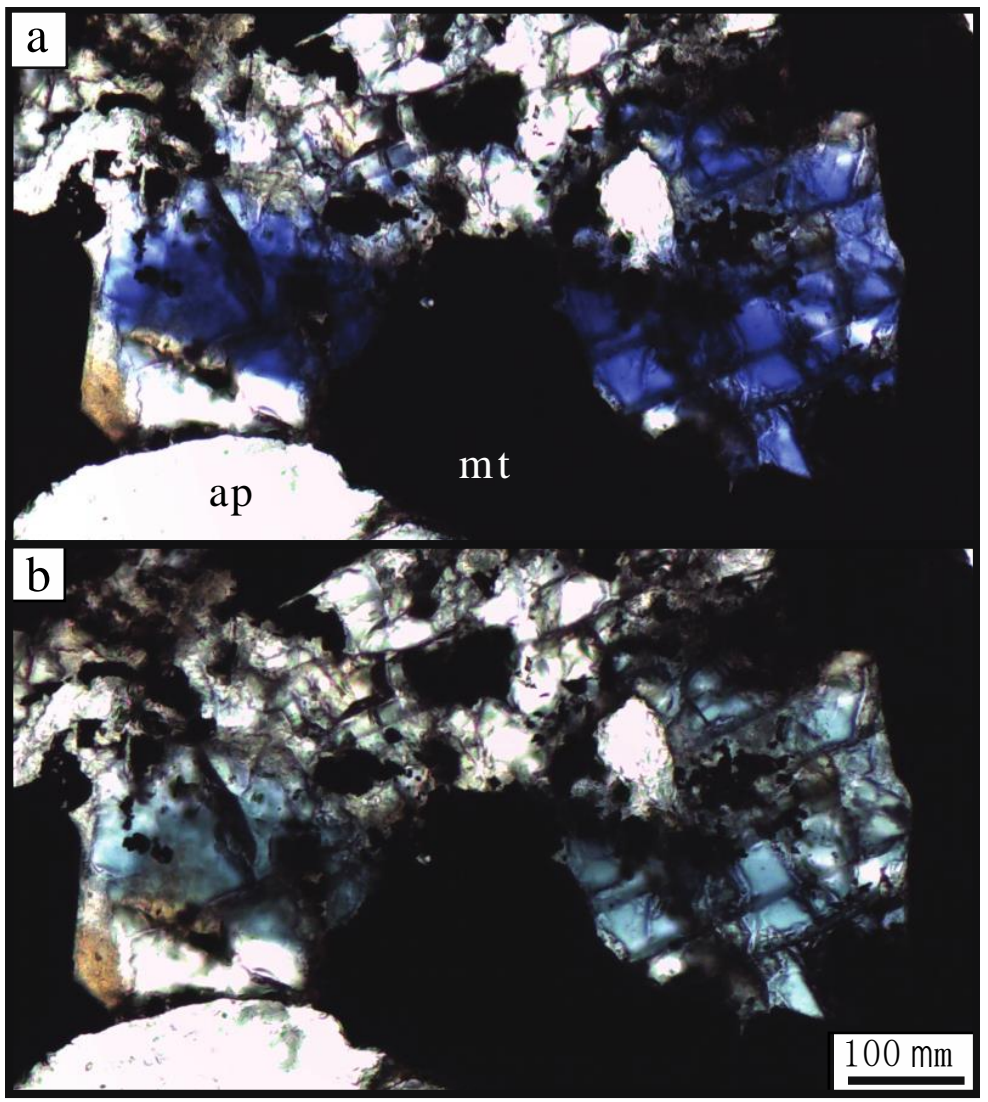

Figure 5. Photomicrographs of sapphire grain surrounded by magnetite (mt) and apatite (ap) showing parting and range of pleochroism in plane polarized light, (a) dark blue color of corundum when omega-ray ( $\omega$-ray) is oriented parallel to lower polar, (b) light blue color of corundum when epsilon-ray ( $\varepsilon$-ray) is oriented parallel to lower polar. 


\section{Sapphire Composition}

The corundum grains were analyzed on Japan Electron Optics Laboratory (JEOL) electron microprobe (JXL 8900) at Binghamton University, Binghamton, NY, USA. Natural and synthetic standards of $\mathrm{SiO}_{2}, \mathrm{TiO}_{2}, \mathrm{Al}_{2} \mathrm{O}_{3}, \mathrm{Fe}_{2} \mathrm{O}_{3}, \mathrm{FeCr}_{2} \mathrm{O}_{4}, \mathrm{~V}$ metal, $\mathrm{MgO}$, and $\mathrm{GaAs}$ supplied by the C.M. Taylor Company were used in the analysis. The instrument was operated at an acceleration voltage of $15 \mathrm{kV}$, and a current of $1.05 \times 10^{-8}$ amperes. Count times on measured peaks were $10 \mathrm{~s}$; off peak measured background on either side of the peak was $3 \mathrm{~s}$. ZAF (atomic number, absorption, fluorescence) correction procedures were employed in the analyses.

Table 1 lists analyses of two clear and six blue corundum grains. The two clear corundum grains analyzed were outer rims of grains in contact with magnetite similar to the left side of the sapphire shown in Figure 4a. The blue corundum grains selected were homogenous in color and showed little or no oscillatory zoning. The corundum shows roughly similar levels of $\mathrm{FeO}$ in both clear $(0.71-0.75 \mathrm{wt}$. \%) and blue (0.38-0.77 wt. \%) portions of grains, but clear sections have significantly lower $\mathrm{TiO}_{2}$ levels (0.002-0.011 wt. \%) compared to blue sections (0.219-0.470 wt. \%). As shown in Figure 6, the $\mathrm{TiO}_{2}$ abundances in the blue sections of corundum crystals are relatively high, with higher $\mathrm{TiO}_{2}$ abundances (up to $1.01 \mathrm{wt}$. \%) being reported from sapphires occurring only at Xanthi and Ikaria Island, Greece [18], and Westland New Zealand [19]. Lower $\mathrm{TiO}_{2}$ abundances are reported for sapphires from Naxos Island, Greece [18], Puente Negro, Mexico [3], Dak Nong, Vietnam [20], Yogo Gulch, MT, USA [21], Desi-Menet-Turkana, Kenya [22], and Ilmen, Russia [23]. $\mathrm{Cr}_{2} \mathrm{O}_{3}$ and $\mathrm{V}_{2} \mathrm{O}_{3}$ abundances are variable, with no real systematic change between clear and blue parts of grains (Table 1). Small amounts of $\mathrm{MgO}$ were detected in one of the clear corundum grains ( $0.013 \mathrm{wt} . \%)$ and two of the six blue grains (0.001-0.015 wt. \%), but the remaining five grains were below the limit of detection. $\mathrm{Ga}_{2} \mathrm{O}_{3}$, however, was detected in five out of six blue-colored grains (0.026-0.097 wt. \%) but was below the limits of detection for clear grains.

Ti numbers (formula units $\mathrm{Ti} / \mathrm{Ti}+\mathrm{Fe}$ ) in blue sections of grains range from 21.1 to 35.4 , values that are a little lower than one would expect $(\sim 50)$ if only a coupled $\mathrm{Fe}^{2+} \& \mathrm{Ti}^{4+}$ substitution for $\mathrm{Al}^{3+}$ and $\mathrm{Al}^{3+}$ was occurring in the blue sections of the grains. This suggests that the remaining Fe may be trivalent, which is plausible given that remnant ilmenite contains $5 \%$ to $10 \%$ hematite exsolution lamellae. The exsolution lamellae suggest moderate oxygen fugacities during mineral growth [24] assuming ilmenite and corundum are in equilibrium. However, the presence of both $\mathrm{Fe}^{2+}$ and $\mathrm{Fe}^{3+}$ would likely result in yellow-colored portions of grains (rather than clear) and this was not observed under the petrographic microscope or the optical spectrometer (see next section). It is possible that the charge balance is maintained by a quadrivalent ion (e.g., $\left.\mathrm{Si}^{4+}\right)$, by the presence of hydrogen $\left(\mathrm{H}^{+}\right)$, by an oxygen vacancy, or interstitial $\mathrm{Al}^{3+}$ ions [25].

Table 1. Select corundum compositions from sample BD-35-93 ${ }^{\mathrm{a}}$.

\begin{tabular}{|c|c|c|c|c|c|c|c|c|}
\hline Color & Clear & Clear & Blue & Blue & Blue & Blue & Blue & Blue \\
\hline Analysis & $1-007$ & $1-016$ & $1-001$ & $1-009$ & $1-013$ & $1-020^{b}$ & $2-031^{a}$ & $2-05$ \\
\hline $\mathrm{SiO}_{2}$ & 0.024 & - & 0.002 & 0.014 & - & - & 0.017 & - \\
\hline $\mathrm{TiO}_{2}$ & 0.002 & 0.011 & 0.470 & 0.334 & 0.359 & 0.251 & 0.226 & 0.219 \\
\hline $\mathrm{Al}_{2} \mathrm{O}_{3}$ & 99.507 & 99.556 & 97.729 & 98.200 & 99.454 & 99.993 & 99.90 & 100.281 \\
\hline $\mathrm{FeO}$ & 0.706 & 0.750 & 0.770 & 0.589 & 0.685 & 0.591 & 0.762 & 0.383 \\
\hline $\mathrm{Cr}_{2} \mathrm{O}_{3}$ & 0.020 & - & 0.079 & 0.072 & 0.038 & 0.006 & 0.018 & 0.051 \\
\hline $\mathrm{V}_{2} \mathrm{O}_{3}$ & 0.020 & 0.042 & 0.075 & 0.010 & 0.077 & 0.024 & 0.013 & 0.022 \\
\hline $\mathrm{MgO}$ & 0.013 & - & - & 0.001 & 0.015 & - & - & - \\
\hline $\mathrm{Ga}_{2} \mathrm{O}_{3}$ & - & - & 0.056 & 0.097 & 0.026 & - & 0.052 & 0.041 \\
\hline Total & 100.292 & 100.359 & 99.181 & 99.317 & 100.654 & 100.865 & 100.990 & 100.997 \\
\hline \multicolumn{9}{|c|}{ Atoms per formula unit ${ }^{b}$} \\
\hline $\mathrm{Si}$ & 0.00041 & 0.00000 & 0.00003 & 0.00024 & 0.00000 & 0.00000 & 0.00029 & 0.00000 \\
\hline $\mathrm{Ti}$ & 0.00003 & 0.00014 & 0.00608 & 0.00431 & 0.00457 & 0.00319 & 0.00287 & 0.00278 \\
\hline $\mathrm{Al}$ & 1.99154 & 1.99214 & 1.98172 & 1.98610 & 1.98534 & 1.98978 & 1.98764 & 1.99128 \\
\hline
\end{tabular}


Table 1. Cont.

\begin{tabular}{ccccccccc}
\hline $\mathrm{Fe}$ & 0.01003 & 0.01065 & 0.01108 & 0.00845 & 0.00970 & 0.00835 & 0.01076 & 0.00540 \\
$\mathrm{Cr}$ & 0.00027 & 0.00000 & 0.00107 & 0.00098 & 0.00051 & 0.00008 & 0.00024 & 0.00068 \\
$\mathrm{~V}$ & 0.00027 & 0.00057 & 0.00103 & 0.00014 & 0.00105 & 0.00032 & 0.00018 & 0.00030 \\
$\mathrm{Mg}$ & 0.00066 & 0.00000 & 0.00000 & 0.00003 & 0.00038 & 0.00000 & 0.00000 & 0.00000 \\
$\mathrm{Ga}$ & 0.00000 & 0.00000 & 0.00062 & 0.00107 & 0.00028 & 0.00000 & 0.00056 & 0.00044 \\
\hline Cations & 2.00320 & 2.00350 & 2.00165 & 2.00131 & 2.00184 & 2.00172 & 2.00253 & 2.00087 \\
\hline $\mathrm{Ti}^{\mathrm{c}}$ & 0.30 & 1.30 & 35.43 & 33.78 & 32.03 & 27.64 & 21.06 & 33.99 \\
\hline
\end{tabular}

a Determined by electron microprobe (at Binghamton University; - below detection). ${ }^{\mathrm{b}}$ Formula units based on three oxygens. ${ }^{\mathrm{c}}$ Ti number $=($ formula units $\mathrm{Ti} / \mathrm{Ti}+\mathrm{Fe}) \times 100$.

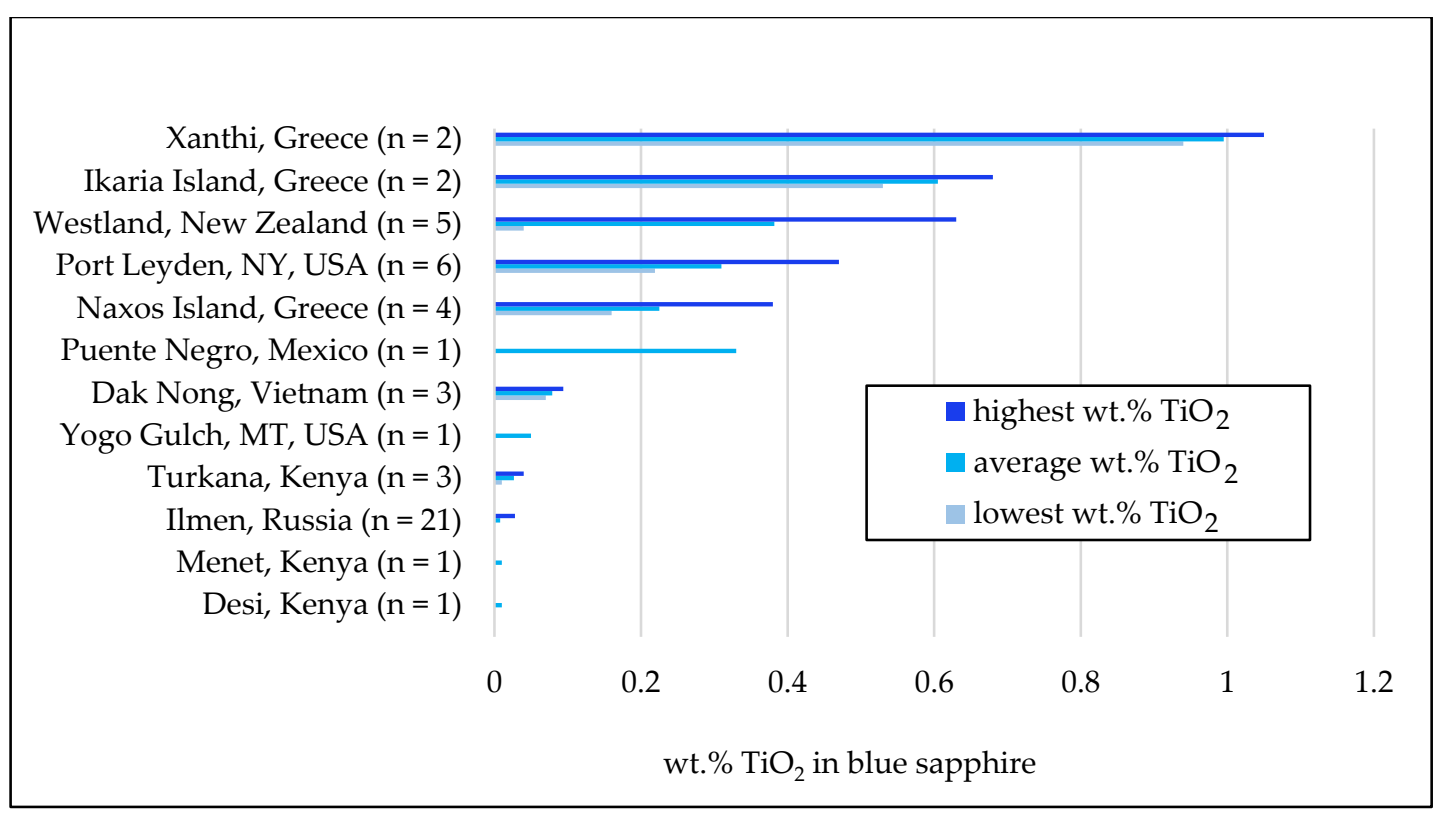

Figure 6. Bar graph showing wt. \% $\mathrm{TiO}_{2}$ in sapphires from Xanthi, Greece [18], Ikaria Island, Greece [18], Westland, New Zealand [19], Port Leyden, NY, USA (this study); Naxos Island, Greece [18], Puente Negro, Mexico [3], Dak Nong, Vietnam [20], Yogo Gulch, MT, USA [21], and Desi-Menet-Turkana, Kenya [22], and Ilmen, Russia [23].

\section{Sapphire Optical Spectroscopy}

The blue color of sapphire is commonly attributed to intervalence charge transfer (IVCT) between the next nearest neighbor $\mathrm{Fe}^{2+}$ and $\mathrm{Ti}^{4+}$ or $\mathrm{Fe}^{2+}$ and $\mathrm{Fe}^{3+}$ ions [26-29]. To help quantify and better understand these chromophores in the Port Leyden microscopic sapphires, we analyzed the corundum grains using a UV-Vis-near IR optical spectrometer in the Department of Biomedical Sciences at Cornell University, Ithaca, NY, USA. Specifically, polished thin sections of sapphire-bearing nelsonite $(30 \mu \mathrm{m}$ thick) were placed under an optical microscope equipped with a $20 \times$ quartz objective operating in epi-illumination mode. A xenon light source (Applied Fiberoptics Brite Lite III) irradiated the specimen. The reflected radiation was collected by a quartz fiber with a diameter of $200 \mu \mathrm{m}$ attached to an Ocean Optics USB2000 UV-visible spectrometer. The wavelength was calibrated using a Hg-Xe lamp (Oriel). No attempt was made to select sapphire grains with a specific optical orientation (e.g., parallel or perpendicular to the c-axis). Rather, inclusion-free, clear- or blue-colored corundum grains were targeted. Optical spectra from both corundum grain types (clear and blue) were obtained from 189.62 to $904.15 \mathrm{~nm}$ (average resolution $=0.35 \mathrm{~nm} / \mathrm{pixel}$ ), although only data between 300 and $900 \mathrm{~nm}$ are shown in Figure 7 .

Transmission spectra were collected with the same optical setup, but with the microscope in transmission mode. Fifteen blue areas and 6 clear areas of corundum grains were selected for measurement. The spectra for both corundum grain types were normalized to obtain "equal" light conditions. Specifically, optical spectra from both corundum grain types (clear and blue) were recorded for each wavelength 
increment and total counts summed. Each analysis was multiplied by a normalization factor so that the sum of total counts equaled the analysis with the highest count total (hence equal light conditions). The mean values along with $2 \sigma$ (95\% confidence limits) for clear and blue corundum are shown in Figure 7a. The relative absorbance curve, as calculated according to [28] $\left(-\log _{10} I / I_{0}\right.$ where $I=$ average normalized counts for clear corundum and $I_{0}=$ average normalized counts for blue corundum), is shown in Figure 7b. As illustrated in Figure 7b, much absorbance occurs in the yellow, orange, and red part of the spectrum $(\sim 565-740 \mathrm{~nm})$ with the greatest absorbance occurring at about $635 \mathrm{~nm}$. This broad absorbance curve is typical for $\mathrm{Fe}^{2+}-\mathrm{Ti}^{4+}$ IVCT $[22,25,30]$ and is inferred to cause the deep blue color of the Port Leyden sapphires. Note, that no absorption peaks are observed at 376, 386, or $451 \mathrm{~nm}$, so $\mathrm{Fe}^{2+}-\mathrm{Fe}^{3+}$ ICVT charge transfer is unlikely to be occurring in the Port Leyden sapphires $[22,25,30]$.

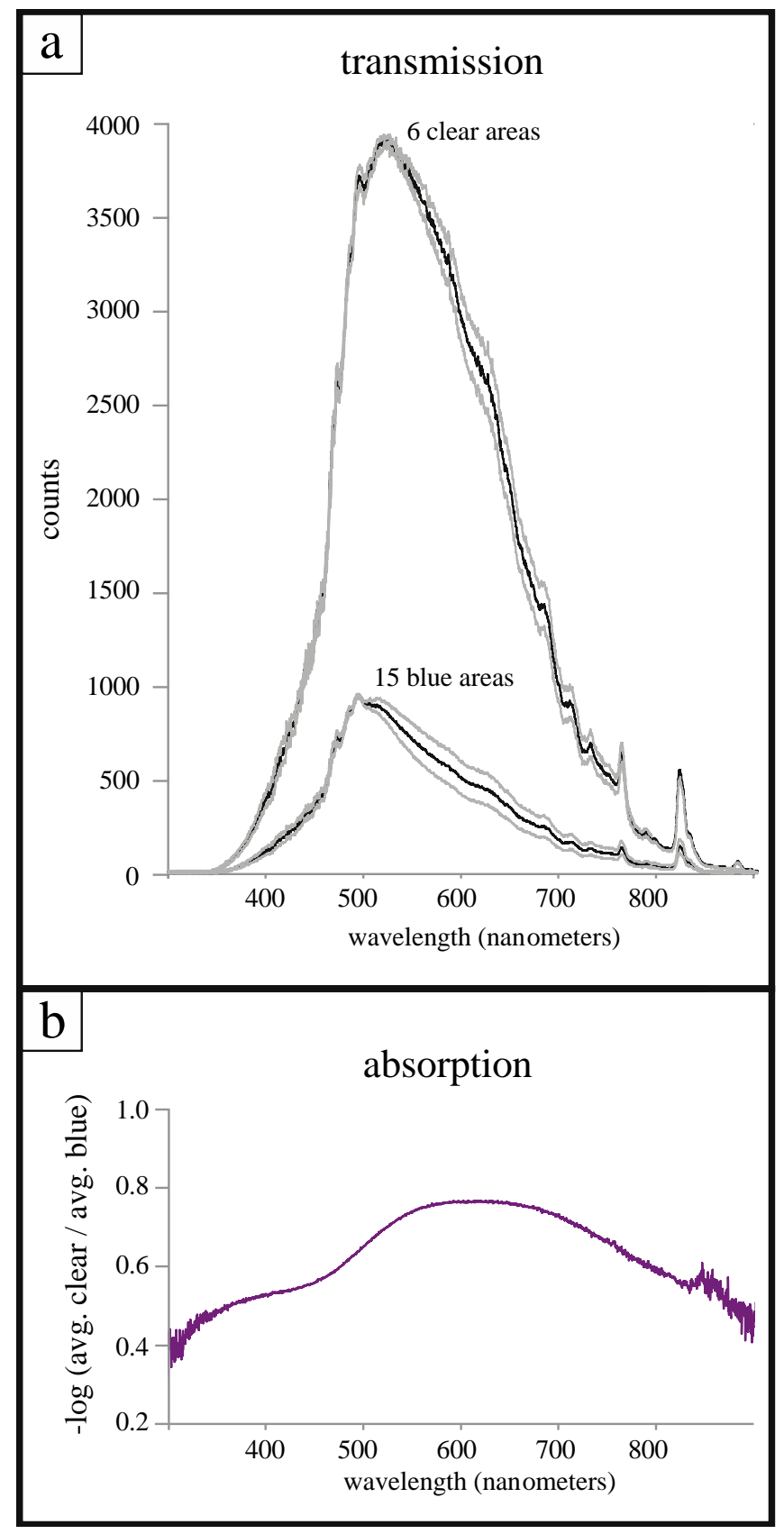

Figure 7. UV-Vis-near IR optical spectra from 15 blue sapphires and 6 clear corundum grains, (a) transmission data from 300 to $900 \mathrm{~nm}$, (b) absorption data over the same wavelength range. See text for further discussion. 


\section{Origin of the Sapphires}

\subsection{Petrologic Considerations}

As mentioned earlier, sapphire formation in rocks has been attributed to a wide variety of processes, including primary igneous crystallization, xenocrysts in alkali igneous rocks, metamorphic, metasomatic, and anatectic origins [1,2]. Any of these processes could conceivably operate in granulite-facies Adirondack rocks, so all warrant some consideration; however, an igneous origin is favored here for two petrologic reasons. One, the microscopic sapphires occur only inside a small slice of nelsonite dike, a rock strongly affiliated with the igneous anorthosite-suite [4-7]. Furthermore, the fine, hexagonal compositional zoning commonly found in these sapphires (Figures $3 \mathrm{a}$ and $4 \mathrm{~b}-\mathrm{d}$ ) suggest growth from a fluid-most likely a melt [31-33].

If the sapphires are igneous in origin, and crystallized as part of the anorthosite suite, an original high magmatic temperature (e.g., $1000-1200{ }^{\circ} \mathrm{C}$, [34-36]) would be consistent with the aforementioned high abundances of $\mathrm{TiO}_{2}$ assuming the solubility of $\mathrm{Fe}$ and $\mathrm{Ti}$ in corundum is directly related to temperature (no experimental data exist for the $\mathrm{Al}_{2} \mathrm{O}_{3}-\mathrm{FeTiO}_{3}$ system). Such a melt likely supplied the $\mathrm{Fe}$ and $\mathrm{Ti}$, which is necessary for the blue color. If so, this may explain why metamorphic corundum, formed at 700 to $880{ }^{\circ} \mathrm{C}$ in the Adirondacks, is colorless even when in apparent equilibrium with a Fe ${ }^{2+}-\mathrm{Ti}^{4+}$ source like ilmenite [37]. These metamorphic occurrences of corundum are inferred to be restitic in origin, forming the melanosomes of anatectic processes [37]. However, a recent report of red corundum from the Adirondack Lowlands [38] is interpreted as igneous.

Although two lines of petrologic evidence support an igneous origin, it is important to note that the host rock of the sapphire-bearing nelsonite dike is sillimanite-bearing (i.e., highly aluminous) and thus a metamorphic or anatectic origin of the sapphires cannot be ruled out. It is possible that a metamorphic or anatectic reaction between the host rock and the small nelsonite dike caused $\mathrm{Al}$ enrichment in the sapphire-bearing nelsonite dike. However, inferred melting reactions at the margin of the Port Leyden nelsonite dike show no evidence of Al enrichment [39]. Only the additional growth of garnet, biotite, and plagioclase is recognized at the contact between the nelsonite and its aluminous gneiss country rocks [39]. Other than corundum, the only phase in the sapphire-bearing nelsonite dike that contains significant $\mathrm{Al}$ is hercynite. The coexistence of hercynite and magnetite indicate subsolvus formation temperatures of less than $800{ }^{\circ} \mathrm{C}$ [40], suggesting the hercynite may be of later metamorphic origin. It is possible that oxidation of hercynite could be responsible for the generation of sapphire (and additional magnetite). However, the lower temperatures necessary to stabilize hercynite and magnetite may be inconsistent with incorporation of high amounts of Fe and Ti in corundum.

\subsection{Trace Element Considerations:}

Studies of trace elements have been used to help better understand the origin of sapphire (see $[2,41,42]$ ). These studies have focused mostly on the distribution of $\mathrm{Fe}, \mathrm{Ti}, \mathrm{Mg}, \mathrm{Ga}, \mathrm{Cr}$, and $\mathrm{V}$ in sapphire as a function of deposit type.

First, as proposed by [41] and further applied by [2,42], the $\mathrm{Ga} / \mathrm{Mg}$ ratio is a useful discriminator of metamorphic versus magmatic sapphire. $\mathrm{Ga} / \mathrm{Mg}$ ratios greater than 6 are thought to be indicative of magmatic origin, whereas $\mathrm{Ga} / \mathrm{Mg}$ ratios of less than 3 are indicative of metamorphic origin [43]. As shown in Table 1, the two clear corundum grains (analyses 1-007, 1-016) have no detectable $\mathrm{Ga}_{2} \mathrm{O}_{3}$, and one grain has $0.013 \mathrm{wt}$. \% MgO. Both of these corundum analyses were derived from clear, outer edges of corundum grains in contact with magnetite, and could have had their trace element chemistry (and color) altered during the Ottawan metamorphism. The $\mathrm{Ga} / \mathrm{Mg}$ ratio of sample 1-007 clearly suggests a metamorphic origin. However, five of the six blue sapphires listed in Table 1 have $\mathrm{Ga}_{2} \mathrm{O}_{3}$ contents ranging from 0.026 to $0.097 \mathrm{wt}$. \% and two (analyses 1-009 and 1-013) of the six blue sapphires have $\mathrm{MgO}$ contents of 0.001 to 0.015 wt. \%. Sapphire 1-013 has a Ga/Mg ratio of 2.1 (when calculated after converting from weight percent oxide to ppm metal), whereas sapphire 1-009 has a $\mathrm{Ga} / \mathrm{Mg}$ ratio of 119.6. $\mathrm{Ga} / \mathrm{Mg}$ ratios of the remaining three blue sapphires could not be calculated because no $\mathrm{MgO}$ 
was detected, however, even if small amounts of $\mathrm{MgO}$ (e.g., up to 0.007 wt. \% or 42.21 ppm) were detected in the three sapphire grains, the $\mathrm{Ga} / \mathrm{Mg}$ ratios would be greater than 6 . Therefore, four of the six blue corundum grains have $\mathrm{Ga} / \mathrm{Mg}$ ratios consistent with a magmatic origin, and one is consistent with a metamorphic origin.

Other variation diagrams are illustrated in Figure 8. Both the Fe- $\mathrm{Mg}(\times 100)-\mathrm{Ti}(\times 10)$ and $\mathrm{Cr}(\times 10)-\mathrm{Fe}-\mathrm{Ga}(\times 100)$ ternary plots show five out of six blue sapphires as magmatic in origin and one blue sapphire as metamorphic in origin (Figure 8a,b). Conversely, the $\mathrm{Cr} / \mathrm{Ga}$ versus Fe/Ti plot shows all blue sapphires falling into the metamorphic field (Figure 8c). Lastly, the proposed $\mathrm{FeO}+\mathrm{TiO}_{2}+$ $\mathrm{Ga}_{2} \mathrm{O}_{3}$ versus $\mathrm{FeO}-\mathrm{Cr}_{2} \mathrm{O}_{3}-\mathrm{MgO}-\mathrm{V}_{2} \mathrm{O}_{3}$ discrimination diagram [2] shows that Port Leyden sapphires show the greatest similarity to sapphires from alkali basalts, but overlap some with sapphires from syenites, and the clear corundum grains fall into the metasomatic/metamorphic field (Figure 8d).

In summary, three out of the four discrimination diagrams in Figure 8 and the $\mathrm{Ga} / \mathrm{Mg}$ ratios largely favor a magmatic origin for the Port Leyden microsapphires, yet some trace element data support a metamorphic origin. The ambiguity in determining sapphire origin based on trace element abundance here is not limited to the Port Leyden occurrence (see for example [44]). Assuming the microsapphires are of magmatic origin, it is the elevated levels of $\mathrm{Cr}$ that result in their plotting in the metamorphic field of Figure 8c. The source of the $\mathrm{Cr}$ in the Port Leyden microsapphires is unclear, as there are no known (surface) ultramafic rocks within $100 \mathrm{~km}$ [45] of the Port Leyden occurrence.

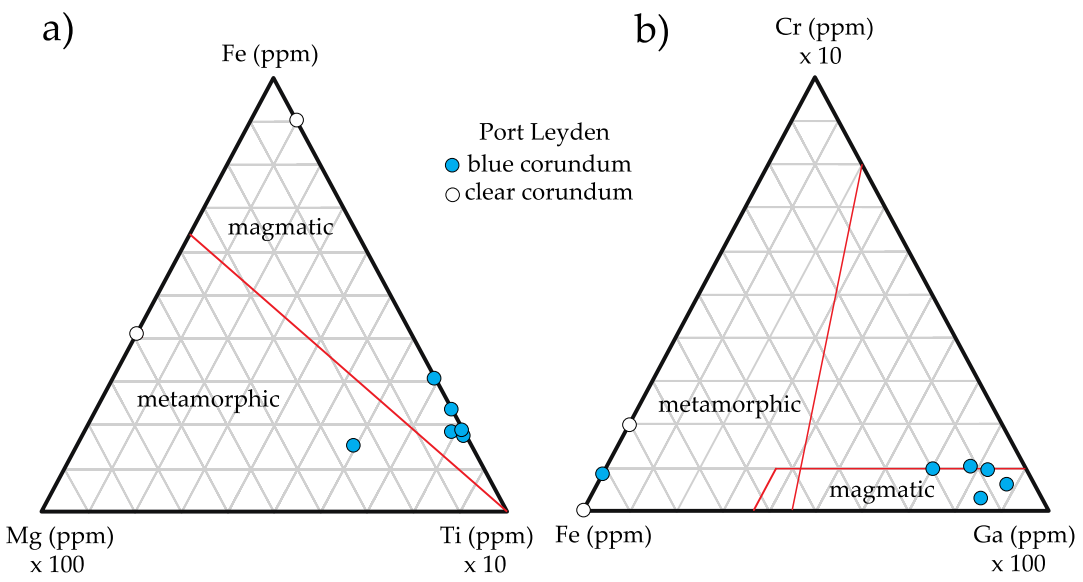

c)

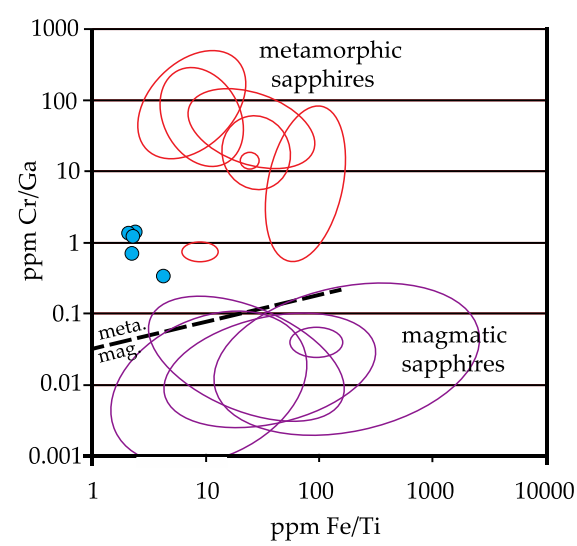

d)

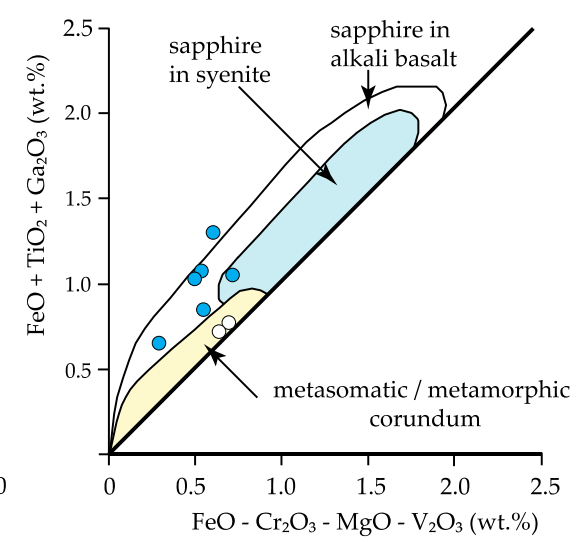

Figure 8. Trace element variation diagrams for sapphire origin along with data from the Port Leyden microsapphires. (a) Fe- $\mathrm{Mg}(\times 100)-\mathrm{Ti}(\times 10)$ ternary plot adapted from [41], (b) $\mathrm{Cr}(\times 10)-\mathrm{Fe}-\mathrm{Ga}(\times 100)$ ternary plot adapted from [42,46], (c) $\mathrm{Cr} / \mathrm{Ga}$ versus Fe/Ti plot adapted from [42]. Red and violet ellipses from metamorphic and magmatic deposits, respectively, (d) sapphire-bearing portion of $\mathrm{FeO}+\mathrm{TiO}_{2}+$ $\mathrm{Ga}_{2} \mathrm{O}_{3}$ versus $\mathrm{FeO}-\mathrm{Cr}_{2} \mathrm{O}_{3}-\mathrm{MgO}-\mathrm{V}_{2} \mathrm{O}_{3}$ plot adapted from [2], Cr-rich ruby deposits not shown. 


\section{Significance and Conclusions}

The microscopic sapphires described in this report are not gem quality because they are too small, and too highly fractured for even the smallest gem material. Yet, their presence in a nelsonite dike represents a previously unreported type of occurrence. To our knowledge, sapphire has not been described from nelsonite or any rocks of the anorthosite suite, although rare corundum is reported from nelsonite at the Saint Urbain and Big Island deposits [47,48]. At the Big Island dike deposit at Lac Allard, Quebec the $\mathrm{TiO}_{2}$ abundance of corundum is 0.01 to $0.08 \mathrm{wt}$. \% [47], which is less than that of the Port Leyden microsapphires. The corundum at both deposits occurs with ilmenite and rutile [47,48], so Ti-saturation can be assumed. Corundum in the Quebec deposits is interpreted as igneous in origin, with estimated crystallization temperatures of 1000 to $1100{ }^{\circ} \mathrm{C}$ [48]. If $\mathrm{TiO}_{2}$ abundance in igneous corundum is directly related to crystallization temperature (assuming $\mathrm{TiO}_{2}$ saturation), then the Port Leyden sapphire may have formed at temperatures greater than $1100{ }^{\circ} \mathrm{C}$. Although a magmatic origin is inferred for both the Port Leyden microsapphires and the aforementioned corundum in Fe-Ti ores, it should be noted that a number of experimental studies show that corundum is not a stable liquidus phase in basaltic melts [49]. The corundum stability field is restricted to very high temperatures $\left(>1400{ }^{\circ} \mathrm{C}\right.$ ) and pressures (7 to $20 \mathrm{~kb}$ ) and narrow (Al-rich) compositions [49]. To our knowledge, no experimental data exist on corundum stability in Fe-Ti-oxide magmas.

Textural evidence and most of the trace element data support a magmatic origin of the Port Leyden microsapphires. However, the elevated $\mathrm{Cr}$ abundances are inconsistent with this model. Further trace element work using laser ablation inductively-coupled plasma mass spectrometry (LA-ICP-MS) would yield results with greater accuracy and possibly lead to a more clear understanding of the sapphire origin.

Author Contributions: Initial identification, petrography, microprobe analyses, R.S.D.; subsequent petrography and mineral formula calculations J.L.G.; optical spectroscopy and interpretation, E.R.L. and R.S.D.; preparation of original draft, R.S.D.; review and editing, R.S.D., J.L.G., E.R.L.

Funding: Publication of this work was supported by the State University of New York, College at Cortland, Offices of Research and Sponsored Programs, and School of Arts and Sciences.

Acknowledgments: We are most grateful for the helpful and constructive comments by G. Giuliani and three anonymous reviewers.

Conflicts of Interest: The authors declare no conflicts of interest.

\section{References}

1. Simonet, C.; Fritsch, E.; Lasnier, B. A classification of gem corundum deposits aimed towards gem exploration. Ore Geol. Rev. 2008, 34, 127-133. [CrossRef]

2. Giuliani, G.; Ohnenstetter, D.; Fallick, A.; Groat, L.; Fagan, A. The geology and genesis of gem corundum deposits. In Geology of Gem Deposits, 2nd ed.; Groat, L., Ed.; Mineralogical Association of Canada Short Course Series 44; Mineralogical Association of Canada: Quebec City, QC, Canada, 2014; pp. 29-112.

3. Ortega-Gutierrez, F.; Martiny, B.M.; Morán-Zenteno, D.J.; Reyes-Salas, A.M.; Solé-Viñas, J. Petrology of very high temperature crustal xenoliths in the Puente Negro intrusion: A sapphire-spinel-bearing Oligocene andesite, Mixteco terrane, southern Mexico. Rev. Mex. Cienc. Geol. 2011, 28, 593-629.

4. Philpotts, A.R. Origin of certain iron-titanium oxide and apatite rocks. Econ. Geol. 1967, 62, $303-315$. [CrossRef]

5. Dymek, R.F.; Owens, B.E. Petrogenesis of apatite-rich rocks (nelsonites and oxide-apatite gabbronorites) associated with massif anorthosites. Econ. Geol. 2001, 96, 797-815. [CrossRef]

6. Charlier, B.; Namur, O.; Bolle, O.; Latypov, R.; Duchesne, J.C. Fe-Ti-V-P ore deposits associated with Proterozoic massif-type anorthosites and related rocks. Earth Sci. Rev. 2015, 141, 56-81. [CrossRef]

7. Duchesne, J.C.; Liégeois, J.P. The origin of nelsonite and high-Zr ferrodiorite associated with Proterozoic anorthosite. Ore Geol. Rev. 2015, 71, 40-56. [CrossRef] 
8. Darling, R.S.; Florence, F.P. Apatite light rare earth chemistry of the Port Leyden nelsonite, Adirondack Highlands, NY: Implications for the origin of nelsonite in anorthosite suite rocks. Econ. Geol. 1995, 90, 964-968. [CrossRef]

9. Rivers, T. Assembly and preservation of lower, mid, and upper orogenic crust in the Grenville Province-Implications for the evolution of large hot long-duration orogens. Precambrian Res. 2008, 167, 237-259. [CrossRef]

10. McLelland, J.M.; Selleck, B.W.; Bickford, M.E. Review of the Proterozoic evolution of the Grenville Province, its Adirondack outlier, and the Mesoproterozoic inliers of the Appalachians. In From Rodinia to Pangea: Lithotectonic Record of the Appalachian Region. Geological Society of America Memoir 206; Tollo, R.P., Bartholomew, M.J., Hibbard, J.P., Karabinos, P.M., Eds.; Geological Society of America: Boulder, CO, USA, 2010; pp. 21-49.

11. Florence, F.P.; Darling, R.S.; Orrell, S.E. Moderate pressure metamorphism and anatexis due to anorthosite intrusion, western Adirondack Highlands, New York. Contrib. Miner. Petrol. 1995, 121, 424-436. [CrossRef]

12. Darling, R.S. Zircon-bearing, crystallized melt inclusions in peritectic garnet from the western Adirondack Mountains, New York State, USA. Geofluids 2013, 13, 453-459. [CrossRef]

13. Darling, R.S.; Florence, F.P.; Lester, G.W.; Whitney, P.R. Petrogenesis of prismatine-bearing metapelitic gneiss along the Moose River, west-central Adirondacks, New York. In Proterozoic Tectonic Evolution of the Grenville Orogen in North America. Geological Society of America Memoir 197; Tollo, R.P., Corriveau, L., McLelland, J., Bartholomew, M.J., Eds.; Geological Society of America: Boulder, CO, USA, 2004; pp. 325-336.

14. Storm, L.C.; Spear, F.S. Application of the titanium-in-quartz thermometer in pelitic migmatites from the Adirondack Highlands, New York. J. Metamorph. Geol. 2009, 27, 479-494. [CrossRef]

15. Darling, R.S. Geology of the Black River Valley and the Western Adirondacks. In Field Trip Guidebook for the 84th Annual Meeting of the New York State Geological Association, 28-30, September 2012, Clinton, NY, USA; Rayne, T., Ed.; New York State Geological Association, 2012; pp. A1-A22.

16. White, J.S. Boehmite exsolution in corundum. Am. Mineral. 1979, 64, 1300-1302.

17. Klapper, H. Generation and propagation of defects during crystal growth. In Springer Handbook of Crystal Growth; Dhanaraj, G., Byrappa, K., Prasad, V., Dudley, M., Eds.; Springer: Berlin, Germany, 2010; pp. $93-132$.

18. Voudouris, P.; Mavrogonatos, C.; Graham, I.; Giuliani, G.; Melfos, V.; Karampelas, S.; Karantoni, V.; Wang, K.; Tarantola, A.; Zaw, K.; et al. Gem Corundum Deposits of Greece: Geology, Mineralogy and Genesis. Minerals 2019, 9, 49. [CrossRef]

19. Grapes, R.; Palmer, K. (Ruby—Sapphire)—Chromian Mica-Tourmaline Rocks from Westland, New Zealand. J. Petrol. 1996, 37, 293-315. [CrossRef]

20. Izokh, A.E.; Smirnov, S.Z.; Egorova, V.V.; Anh, T.T.; Kovyazin, S.V.; Phuong, N.T.; Kalinina, V.V. The conditions of formation of sapphire and zircon in the areas of alkali-basaltoid volcanism in Central Vietnam. Rus. Geol. Geophys. 2010, 51, 719-733. [CrossRef]

21. Meyer, H.; Mitchell, R. Sapphire-bearing ultramafic lamprophyre from Yogo, Montana: A ouachitite. Can. Miner. 1988, 26, 81-88.

22. Simonet, C.; Paquette, J.L.; Pin, C.; Lasnier, B.; Fritsch, E. The Dusi (Garba Tula) sapphire deposit, Central Kenya-A unique Pan-African corundum-bearing monzonite. J. Afr. Earth Sci. 2004, 38, 401-410. [CrossRef]

23. Sorokina, E.S.; Karampelas, S.; Nishanbaev, T.P.; Nikandrov, S.N.; Semiannikov, B.S. Sapphire megacrysts in syenite pegmatites from the Ilmen Mountains, South Urals, Russia: New mineralogical data. Can. Miner. 2017, 55, 823-843. [CrossRef]

24. Spencer, K.J.; Lindsley, D.H. A solution model for coexisting iron-titanium oxides. Am. Miner. 1981, 66, 1189-1201.

25. Emmett, J.L.; Scarratt, K.; McClure, S.F.; Moses, T.; Douthit, T.R.; Hughes, R.; Novak, S.; Shigley, J.E.; Wang, W.; Bordelon, O.; et al. Beryllium diffusion of ruby and sapphire. Gems Gemol. 2003, 39, 84-135. [CrossRef]

26. Nassau, K. The origins of color in minerals. Am. Miner. 1978, 63, 219-229.

27. Burns, R.G. Intervalence transitions in mixed-valence minerals of iron and titanium. Annu. Rev. Earth Planet. Sci. 1981, 9, 345-383. [CrossRef]

28. Fritsch, E.; Rossman, G.R. An update on color in gems. Part II. Colors caused by charge transfers and color centers. Gems Gemol. 1988, 24, 3-15. [CrossRef]

29. Rossman, G.R. Optical spectroscopy. Rev. Miner. Geochem. 2014, 78, 371-398. [CrossRef] 
30. Sutherland, F.L.; Duroc-Danner, J.M.; Meffre, S. Age and origin of gem corundum and zircon megacrysts from the Mercaderes-Rio Mayo area, South-west Colombia, South America. Ore Geol. Rev. 2008, 34, 155-168. [CrossRef]

31. Shore, M.; Fowler, A.D. Oscillatory zoning in minerals; a common phenomenon. Can. Miner. 1996, 34, 1111-1126.

32. Upton, B.G.J.; Hinton, R.W.; Aspen, P.; Finch, A.; Valley, J.W. Megacrysts and associated xenoliths: Evidence for migration of geochemically enriched melts in the upper mantle beneath Scotland. J. Petrol. 1999, 40, 935-956. [CrossRef]

33. Keller, D.S.; Ague, J.J. High-pressure granulite facies metamorphism ( 1.8 GPa) revealed in silica-undersaturated garnet-spinel-corundum gneiss, Central Maine Terrane, Connecticut, USA. Am. Miner. 2018, 103, 1851-1868.

34. Bohlen, S.R.; Essene, E.J. Igneous pyroxenes from metamorphosed anorthosite massifs. Contrib. Miner. Petrol. 1978, 65, 433-442. [CrossRef]

35. Morse, S.A. A partisan review of Proterozoic anorthosites. Am. Miner. 1982, 67, 1087-1100.

36. Ranson, W.A. Complex exsolution in inverted pigeonite; exsolution mechanisms and temperatures of crystallization and exsolution. Am. Miner. 1986, 71, 1322-1336.

37. Powers, R.E.; Bohlen, S.R. The role of synmetamorphic igneous rocks in the metamorphism and partial melting of metasediments, Northwest Adirondacks. Contrib. Miner. Petrol. 1985, 90, 401-409. [CrossRef]

38. Chiarenzelli, J.; Lupulescu, M.; Robinson, G.; Bailey, D.; Singer, J. Age and origin of silicocarbonate pegmatites of the Adirondack Region. Minerals 2019, 9, 508. [CrossRef]

39. Florence, F.P. Melt forming reactions at the Port Leyden nelsonite-pelitic gneiss contact: A disequilibrium record of tectonic history. Geol. Soc. Am. Abstr. Programs 1997, 29, 45.

40. Turnock, A.C.; Eugster, H.P. Fe-Al Oxides: Phase Relationships below $1000{ }^{\circ}$ C. J. Petrol. 1962, 3, $533-565$. [CrossRef]

41. Peucat, J.J.; Ruffault, P.; Fritsch, E.; Bouhnik-Le Coz, M.; Simonet, C.; Lasnier, B. Ga/Mg ratio as a new geochemical tool to differentiate magmatic from metamorphic blue sapphires. Lithos 2007, 98, 261-274. [CrossRef]

42. Sutherland, F.L.; Zaw, K.; Meffre, S.; Giuliani, G.; Fallick, A.E.; Graham, I.T.; Webb, G.B. Gem-corundum megacrysts from east Australian basalt fields: Trace elements, oxygen isotopes and origins. Aust. J. Earth Sci. 2009, 56, 1003-1022. [CrossRef]

43. Sutherland, F.; Zaw, K.; Meffre, S.; Yui, T.F.; Thu, K. Advances in trace element "fingerprinting" of gem corundum, ruby and sapphire, Mogok area, Myanmar. Minerals 2015, 5, 61-79. [CrossRef]

44. Uher, P.; Giuliani, G.; Szakall, S.; Fallick, A.; Strunga, V.; Vaculovic, T.; Ozdin, D.; Greganova, M. Sapphires related to alkali basalts from the Cerová Highlands, Western Carpathians (southern Slovakia): Composition and origin. Geol. Carpath. 2012, 63, 71-82. [CrossRef]

45. Chiarenzelli, J.; Lupulescu, M.; Thern, E.; Cousens, B. Tectonic implications of the discovery of a Shawinigan ophiolite (Pyrites Complex) in the Adirondack Lowlands. Geosphere 2011, 7, 333-356. [CrossRef]

46. Wang, K.K.; Graham, I.T.; Lay, A.; Harris, S.J.; Cohen, D.R.; Voudouris, P.; Belousova, E.; Giuliani, G.; Fallick, A.E.; Greig, A. The origin of a new pargasite-schist hosted ruby deposit from Paranesti, Northern Greece. Can. Miner. 2017, 55, 535-560. [CrossRef]

47. Charlier, B.; Namur, O.; Malpas, S.; De Marneffe, C.; Duchesne, J.-C.; Vander Auwera, J.; Bolle, O. Origin of the giant Allard Lake ilmenite ore deposit (Canada) by fractional crystallization, multiple magma pulses and mixing. Lithos 2010, 117, 119-134. [CrossRef]

48. Morisset, C.E.; Scoates, J.S.; Weis, D.; Sauvé, M.; Stanaway, K.J. Rutile-bearing ilmenite deposits associated with the Proterozoic Saint-Urbain and Lac Allard anorthosite massifs, Grenville Province, Quebec. Can. Miner. 2010, 48, 821-849. [CrossRef]

49. Liu, T.C.; Presnall, D.C. Liquidus phase relationships on the join anorthite-forsterite-quartz at $20 \mathrm{kbar}$ with applications to basalt petrogenesis and igneous sapphirine. Contrib. Miner. Petrol. 1990, 104, 735-742. [CrossRef]

(C) 2019 by the authors. Licensee MDPI, Basel, Switzerland. This article is an open access article distributed under the terms and conditions of the Creative Commons Attribution (CC BY) license (http://creativecommons.org/licenses/by/4.0/). 